\title{
METHOD FOR TECHNICAL AND ECONOMIC EVALUATION OF THE EFFECTIVENESS OF RELIABILITY IMPROVEMENT OF MILITARY AIRCRAFT GAS-TURBINE ENGINES IN THEIR AFTERSALES SUPPORT BASED ON OUTCOME PERFORMANCE MEASURES *
}

\author{
M.R. Asadullin, Deputy Chief of customer relations department of "Aviadvigatel” JSC \\ E-mail: msmk90@mail.ru \\ Joint Stock Company "Aviadvigatel”, \\ 93, Komsomolsky prospekt, GSP, Perm, 614990, Russian Federation
}

The article describes a conflict between interests of the state customer and the prime contractor on the issue of aeronautical systems and subsystems reliability improvement during its aftersales support. The conflict between interests is shown to arise under the traditional approach to payment for the prime contractor's services on a basis called "costs+". Contractual models of public-and-private partnership which are used in the foreign countries successfully, with a payment scheme for the contractor's services based on outcome performance measures of aeronautical systems and subsystems aftersales support, are presented as a conflict settlement mechanism. A long validity term of such contracts and independence of performance payment amounts from the contractor's actual expenses motivate the private partner to hold some activities aiming at systems and subsystems reliability improvement. Applicability of technical and economic assessment of these activities is demonstrated. The main provisions of the method for technical and economic evaluation of the effectiveness of aeronautical systems and subsystems reliability improvement are presented thorough the example of a fleet of engines operated within a group of military transport aircrafts with their aftersales support based on outcome performance measures. The method is based on a simulation model of engines fleet operating which allows for the measures of technical and economic evaluation to be identified: average availability of the military transport aircrafts group during the contract validity period, state customer's operating costs and the prime contractor's profit. It is experimentally shown on the developed method basis that when the fleet of engines is supported aftersales based on outcome performance measures the prime contractor has an economic interest to improve engines reliability above the requirements specified in the regulatory documentation.

Keywords: technical and economic evaluation, simulation modeling, availability of aeronautical systems and subsystems, conflict between interests, aftersales support, outcome performance measures, gas turbine aircraft engine, gas turbine engine reliability, operating time between unscheduled removals, military transport aircraft.

\section{Introduction}

Aftersales support for the aeronautical systems and subsystems (ASS) for the military use involves a payment for the prime contractor's services based on the "costs+" method. However, in spite of competitive procurement procedure presence, maintenance and repair (M\&R) of the aeronautical systems and subsystems of certain types is normally monopolized by its production manufacturer. Under such conditions, the enterprisemonopolist doesn't have an absolute interest in reliability improvement of the produced systems and subsystems with reference to the required values due to objective economic reasons. As a result, a socalled conflict between interests is generated products reliability improvement is beneficial to the state customer as it allows for his operating costs to decrease and availability of aeronautical systems and subsystems fleet to increase, but at the same time it decreases the prime contractor's profit from M\&R services implementation. (ContractNo.02.G25.31.0168 dated 01.12.2015) within execution of RF Government Regulation No. 218 «About Measures of State Support for Development of Higher Education Institutes and Organizations Realizing Comprehensive Projects on High-Technology Manufacture Creation». 
A mechanism to settle the said conflict, widely used in the foreign countries, is considered to be contractual models of public-and-private partnership with a payment scheme for the contractor's services based on outcome performance measures of aftersales support (Performance-based contracts, PBC). Thus, according to the research by Delloite Consulting Company [17] held in 2010, PBCs are becoming a preferable approach to service maintenance of weaponry, military and special machinery models (WMSM). It is noted in the study that the expenses of the US Department of Defense for similar programs increased from $\$ 1,4$ billion in 2001 to $\$ 5$ billion in 2009 , with the average PBC price increasing from $\$ 26,4$ million in $2000-2002$ to $\$ 59,5$ million in 2007-2009. Positive experience in application of such contracts is proved by multiple examples of public-and-private partnership between Air Force offices of USA, Great Britain and Australia and manufacturers of aeronautical systems and subsystems $[16 ; 21 ; 22$, etc.]. In Russia such type of contracts is currently implemented at a pilot projects level [10].

PBCs effectiveness is due to their motivating nature: a long validity time, which is comparable in duration with after-production lifecycle stages of systems and subsystems, and independence of the performance payment amounts from the contractor's actual expenses motivate the private partner to hold activities aiming at his own expenses decrease with simultaneous increase of outcome performance measurements of aftersales support. According to the studies [18; 19; etc.], manufacturers rely on reliability improvement of systems and subsystems most frequently to achieve these goals.

However, if it is practical to hold this activities depends mostly on the offered PBC conditions and requires thorough technical and economic evaluation (TEE). In the foreign literature [18; 19, etc.] such TEE methods are of extremely simplified nature and don't account for a great number of correlated factors and complexity of processes carried in WMSM aftersales support system. In Russian authors' works methods for evaluation of economic effectiveness of reliability improvement are developed for civil AE [8; 15] and cannot be applied to military $\mathrm{AE}$ due to the difference in the goals of the operating enterprises.

In accordance of the abovementioned, one of the relevant measures to settle down the conflict between interests of the manufacturing enterprise and the state customer is to develop a method for technical and economic evaluation of the effectiveness of reliability improvement of domestic military AE with its aftersales support based on outcome performance measures.

\section{Main Provisions}

To specify a scope of studies the following refinements are introduced.

1. A fleet of the same-type gas-turbine aircraft engines, operated within a group of military transport aircrafts (MTA), is regarded as an object relating to which a $\mathrm{PBC}$ is concluded.

2. Operating time between unscheduled engine removals off aircraft wing is regarded as a reliability characteristic.

3. The average availability of the MTA group during the contract validity period is regarded as an outcome performance measure of aftersales support.

4. Availability of an MTA is fully determined by availability of its engines.

5. The average availability of the MTA group for the contract validity period, the state customer's operating costs and the prime contractor's profit are regarded as technical and economic evaluation measures of the engines reliability improvement effectiveness.

The main point of the method includes the measures of technical and economic evaluation being determined with different run times between unscheduled removals, excessing the requirements specified in the regulatory documentation (RD).

The structure of the developed method consists of two blocks - input data and a simulationand-calculation block.

The input data is divided into 7 groups as follows:

1) MTA group properties - a period and rate of MTA group generation, and a size of the engines inventory;

2) Properties of reliability, lifetime and engines maintainability: operating time between unscheduled removals in accordance with the requirements specified in the $\mathrm{RD}$, overhaul life and assigned life of engines, and engine removal/installation time;

3) Properties of the prime contractor's production capacities and repair base - farness of the repair base from the home base of the air regiment, and lead time for an engine heavy overhaul and an emergency and recovery repair;

4) Cost parameters - a price for a new engine, cost of an emergency and recovery repair and cost of a heavy overhaul, the prime contractor's cost behavior for increasing of operating time between unscheduled removals above the requirements specified in the $\mathrm{RD}$, transportation price for 1 engine per 1 kilometer, price for keeping 1 engine in a warehouse for 1 hour and the prime contractor's profit margins;

5) The PBC conditions - the contract validity period, a performance payments function, 
the monitoring period of the average availability of the MTA group; the maximum amount of a performance payment;

6) The MTA application conditions in peacetime - a planned flights table with distribution of typical flight missions and annual average flight hours of 1 MTA;

7) The prime contractor's efforts to improve engines reliability - a rate of engines reliability improvements above the requirements specified in the RD.

The simulation-and-calculation block is presented with an operating model of the engines fleet within the MTA group (Fig. 1). The simulation model allows for evaluation of functional relationship between the measures of technical and economic evaluation and the properties identifying them.

Compared to other widely used methods to model gas-turbine engines operating, such as probabilistic-statistical methods and static test methods [13], mean dynamics method and congestion theories $[8 ; 11 ; 12 ; 14$ etc.], the application of simulation modelling in the method of interest is efficient due to a number of reasons.

1. Complexity of processes proceeding in the system under investigation, and a need to account for a large number of correlated factors when modelling, which complicates adequate analytical models building.

2. A need to monitor the dynamics of the technical and economic evaluation measures under investigation during modelling to implement the PBC conditions: the performance payment function and the monitoring period for average availability of the MTA group.

3. A need to account for the age composition of the engines fleet and dynamics of their reliability measures when modelling actual operating processes.

The present model is development of the model by A.A. Mikhailov [9] in a part of accounting for the prime contactor's efforts to improve operating time between unscheduled engine removals off the aircraft above the requirements specified in the $\mathrm{RD}$, and implementation of the contract conditions of the state customer and prime contractor's interaction during aftersales support for the engines fleet based on outcome performance measures.
The engines fleet operating process within the simulation model is represented as a sequence of equal time steps with the whole engines fleet operating cycle being modelled at each of them, including engines entry into service during the delivery of aircrafts to the state customer, forming and maintaining of the state customer's engines inventory, flights, through-flight inspection with engines and aircraft state evaluation, inoperable engines recovery with some reworks performed to improve their reliability. Herewith, time delays caused by a need to change a failed or overaged engine as well as a possible lack of spare engines stock are accounted for. As a result, current engines fleet availability $A_{e n}^{\text {cur }}$ and current MTA group availability $A_{g r}^{c u r}$ it specifies are identified at each step.

Forming and maintaining of the engines inventory, inoperable engines recovery including their transportation to the repair base and back, as well as engines reworks for their reliability improvement, result in the state customer's operating costs and generate the prime contractor's profit. Consequently, their current values $C_{\text {op }}^{\text {cust.curr }}$ and $\mathrm{Pr}^{\text {cont.curr }}$ are determined at each step of modelling.

When modelling time achieves the end of the contract validity period, the average availability of the MTA group $A_{g r}$, the state customer's operating costs $C_{o p}^{c u s t}$ and the prime contractor's profit $\mathrm{Pr}^{\text {cont }}$ are determined.

The formulas to determine the noted measures with are as follows (1-7).

$$
A_{e n}^{c u r r}=\frac{N_{A e n}(\tau)}{N_{O p . c n}(\tau)} 100 \%
$$

where $N_{\text {Aen }}(\tau)$ is the current number of the engines available;

$N_{\text {Op.en }}(\tau)$ is the current number of operating engines (the inventory included).

$A_{g r}^{c u r r}=f\left(A_{e n}^{c u r r}\right)=\frac{N_{A g r}\left(N_{A e n}(\tau), \tau^{\prime}\right.}{N_{O p, g r}(\tau)} 100 \%$,

where $N_{A g r}\left(N_{A e n}(\tau), \tau\right)$ is the current number of the aircrafts available within the group;

$N_{O p . g r}(\tau)$ - is the current number of the aircrafts within the group. 


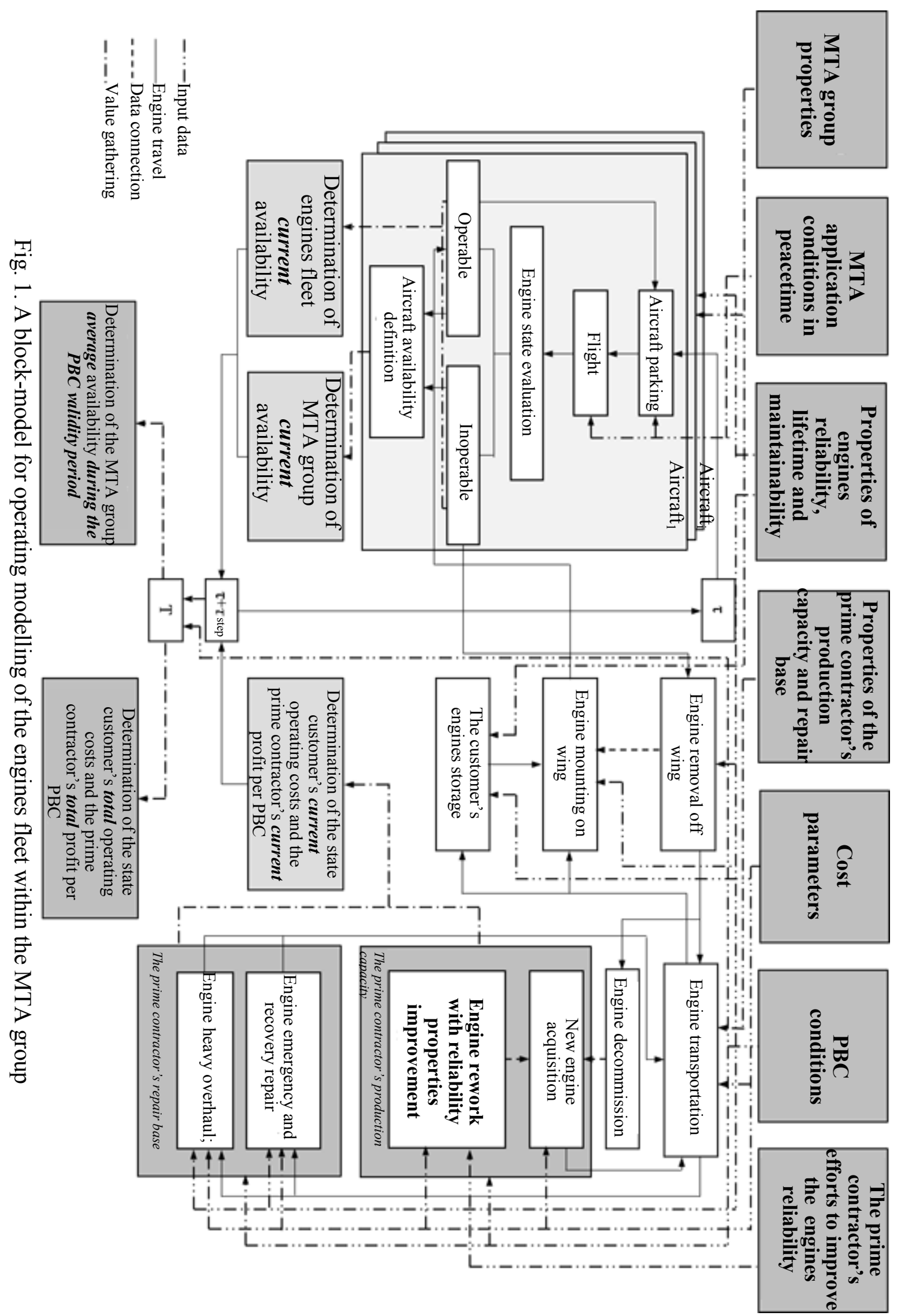


$C_{o p}^{\text {cust.curr. }}=\chi\left(A_{g r}^{\text {curr }}\right)+c_{\text {n.en. }} *\left(N_{\text {inv. }}(\tau)+N_{\text {dec.en. }}(\tau)\right)+$

$+c_{k} * N_{k . e n .}(\tau)+c_{t r .} * \sum_{i=1}^{N_{t r e n}(\tau)} r_{i}\left(\tau_{\text {step }}\right)$

where $\chi\left(A_{g r}^{\text {curr }}\right)$ is the amount of a performance payment, in a case if the current time aligns with a regular monitoring period. Representation of the performance payment function $\chi\left(A_{g r}\right)$ shall be considered later;

$c_{n . e n}$ is the price of a new engine;

$N_{\text {inv. }}(\tau)$ is the number of the engines acquired by the state customer to form the inventory at the current moment;

$N_{\text {dec.en. }}(\tau)$ is the number of the decommissioned engines at the current moment, in exchange for which the state customer acquired new engines;

$c_{k}$ is the price for keeping of one engine in a warehouse for a period equal to a modelling step $\tau_{\text {step; }}$

$N_{\text {k.en. }}(\tau)$ is the number of the engines kept in the warehouse at the current moment;

$c_{t r}$. is the transportation price for one engine to 1 kilometer;

$r_{i}\left(\tau_{\text {step }}\right)$ is the distance travelled by the $i$-th engine for the previous modelling step;

$N_{\text {tr.en. }}(\tau)$ is the number of the engines being transported to the prime contractor's base and back at the current moment.

$\operatorname{Pr}^{\text {cont.curr. }}=I^{\text {cont. }}(\tau)-C^{\text {cont }}(\tau)=$

$\operatorname{Pr}^{\text {cont.curr. }}=I^{\text {cont. }}(\tau)-C^{\text {cont }}(\tau)=$

$=\chi\left(A_{g r}^{\text {curr }}\right)+M_{p r} * c_{\text {n.en. }} *\left(N_{\text {inv. }}(\tau)+N_{\text {dec.en } /}(\tau)\right)-$

$-\left(1-M_{p r}\right)\left(c_{H O} * * N_{H O}(\tau)+c_{E R R} * N_{E R R}(\tau)\right)-c(R, \tau)$

where $I^{\text {cont }}(\tau)$ is the prime contractor's current income;

$C^{\text {cont }}(\tau)$ is the prime contractor's current expense;

$M_{p r}$ is the prime contractor's profit margin;

$c_{H O}$ is the cost of an engine heavy overhaul;

$N_{H O}(\tau)$ is the number of the engines passed through a heavy overhaul at the current moment;

$c_{E R R}$ is the price of an engine emergency and recovery repair;

$N_{E R R}(\tau)$ is the number of the engines passed through an emergency and recovery repair at the current moment;
$c(R, \tau)$ are the prime contractor's current expenses for engines reliability improvements above the requirements specified in the RD.

$$
A_{g r}=\frac{\sum A_{g r}^{c u r r}}{N_{\text {step }}}
$$

where $N_{\text {step }}$ is the number of the times MTA group current availability was determined.

$$
C_{o p}^{\text {cust }}=\frac{\sum C_{o p}^{\text {cust.curr }}}{\tau^{\Sigma}}
$$

where $\tau^{\Sigma}$ is the total operating time of all the engines in the fleet for the period of modelling time.

Operating costs are needed to be calculated per 1 flight hour because they depend on the total operating time of all the engines in the fleet for the period of modelling time, which is, in its turn, due to availability of the MTA group.

$$
P r^{\text {cont }}=\sum P r^{\text {cont.curr }} \text {. }
$$

Let's consider representation of the performance payment function.

In foreign PBC-contacts the most popular representation of the performance payment function is a piecewise type (Formula 8) [20].

$$
\begin{gathered}
\chi\left(A_{i g r}\right)= \\
\alpha_{1}{ }^{*} \chi_{\max }, \text { if } A_{i g r}<A_{g r}^{1}, \\
\alpha_{2}{ }^{*} \chi_{\max }, \text { if } A_{g r}^{1} \leq A_{i g r}<A_{g r}^{2} \\
\cdots \\
\alpha_{n}{ }^{*} \chi_{\max }, \text { if } A_{g r}^{n-1} \leq A_{i g r}<100 \%
\end{gathered}
$$

where $i \in\left[1 ; T_{\text {mon }}\right]$ is the number of the MTA group average availability monitoring period;

$A_{i r g}$ is the MTA group average availability for the $i$-th monitoring period;

$\chi\left(A_{i g r}\right)$ is the amount of the performance payment in the $\boldsymbol{i}$-th monitoring period;

$A_{g r}^{j}=\left(A_{g r}^{1}, A_{g r}^{2}, \ldots, A_{g r}^{n-1}, 100 \%\right) \quad$ are the boundaries of MTA group average availability for the monitoring period, where $j \in[1 ; n]$ is a discreteness degree of a performance payment function;

$\alpha=\left(\alpha_{1}, \alpha_{2}, \ldots, \alpha_{n}\right)$ is a stimulation coefficient of the prime contractor, specifying an amount of fine or bonus depending on the achieved value of the MTA group average availability for the monitoring period;

$\chi_{\max }-$ is the maximum amount of the performance payment, which can be defined as a quotient of the state customer's total expenses for aftersales support for the engines fleet per traditional contracts and a number of monitoring periods of MTA group average availability. 
Engines rework block with reliability properties improvement which has a key value in the developed method is implemented in the presented simulation model of engines fleet operating. Let's consider its performance in more details.

According to a principle of operating-tomanufacture "feedback" involving a constant improvement of an engine, every fault of an engine potentially threatening to flight operation safety or leading to mass unscheduled removal of engines off aircrafts results in designing and engineering activities (DEA) aimed to this fault elimination [2]. Thus, engines reliability is a dynamics variable and increases during engines operating. The required dynamics of reliability properties depending on the engines fleet total accumulated operation time is determined by the $\mathrm{RD}$, particularly by a field performance specification (FPS) for experimental development works to create an engine. But at the same time the prime contractor has a possibility to excess reliability properties values respectively the ones defined in the FPS due to accelerated technological development, though it requires additional industry expenses, profitability of which should be provided by the PBC conditions.

Hence, when modelling the engines rework process with reliability properties improvement, three consequent tasks should be solved:

1) development of an engines reliability improvement algorithm according to the requirements specified in the $\mathrm{RD}$;

2) development of an engines reliability improvement algorithm above the requirements specified in the RD;

3) development of an approach to evaluation of the prime contractor's expenses to improve engines reliability above the requirements specified in the RD.

Let's consider solution of the first task.

The prime contractor should provide improvement of engine reliability according to the FPS, particularly, of operating time between unscheduled engine removals off aircraft $T_{\text {uer }}$, while the total operating time is accumulated by the engines fleet. This dynamics is plotted at Figure 2 showing $T_{\text {uer }}^{\text {FPS }}\left(\tau^{\Sigma}\right)$ ) curve, where $\tau^{\Sigma}$ is the total accumulated opertating time of the engines fleet.

$T_{\text {uer }}$ increase occurs individually for each operating engine as a rule during the process of its rework under the plant conditions, while it is sent for heavy overhaul (HO) after time between overhauls been outlived or for emergency and recovery repair (ERR) after unscheduled removal due to a fault occurrence. This process is modelled by assigning a new $T_{i}$ uer value to each engine passed through repair, which corresponds to the engines fleet total accumulated operating time at the moment of overhaul being performed (Formula 9).

$$
T_{i \text { uer }}=T_{\text {uer }}^{\text {FPS }}\left(\tau^{\Sigma}(t)\right),
$$

where $i$ is an engine counting number;

$\tau^{\Sigma}(t)$ is the engines fleet total accumulated operating time at the current moment $t$;

$t$ is the current moment corresponding to the time repair being performed;

$T_{\text {uer }}^{F P S}\left(\tau^{\Sigma}(t)\right)$ is the operating time between unscheduled removals assigned in the FPS at the engines fleet total accumulated operating time $\tau^{\Sigma}(t)$ at the current time $t$.

At that, the engines of the following groups, delivered within the MTA group and sent for inventory replenishment, have a operating time between unscheduled engine removals increased by $\Delta$ value, where variable $\Delta$ is defined according to Formula 10:

$$
\Delta=T_{u e r}^{F P S}\left(\tau^{\Sigma}(t)\right)-T_{u e r}^{1},
$$

where $T_{\text {uer }}^{1}$ is the initial value of $T_{\text {uer }}$;

$t$ is the current time corresponding to the engines fleet replenishment time.

To solve the second task variable $R$ is introduced describing a rate of improvement of operating time between unscheduled removals above the requirements specified in the RD (Formula 11):

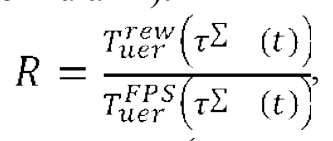

where $T_{\text {uer }}^{\text {rew. }}\left(\tau^{\Sigma}(t)\right)$ is dynamics of increased operating time between unscheduled removals above the requirements specified in the $\mathrm{RD}$ (Fig. 2).

The modelling is performed in a way similar to the above-described algorithm. Every engine passed through repair is assigned with a new $T_{i \text { uer }}^{r e w a l u e, ~ c o r r e s p o n d i n g ~ t o ~ t h e ~ e n g i n e s ~}$ fleet total accumulated operating time at the repair completion moment (Formula 12).

$$
T_{i \text { uer }}^{\text {rew. }}=T_{\text {uer }}^{\text {rew. }}\left(\tau^{\Sigma}(t)\right)=T_{\text {uer }}^{\text {FPS }}\left(\tau^{\Sigma}(t)^{*} R,\right.
$$




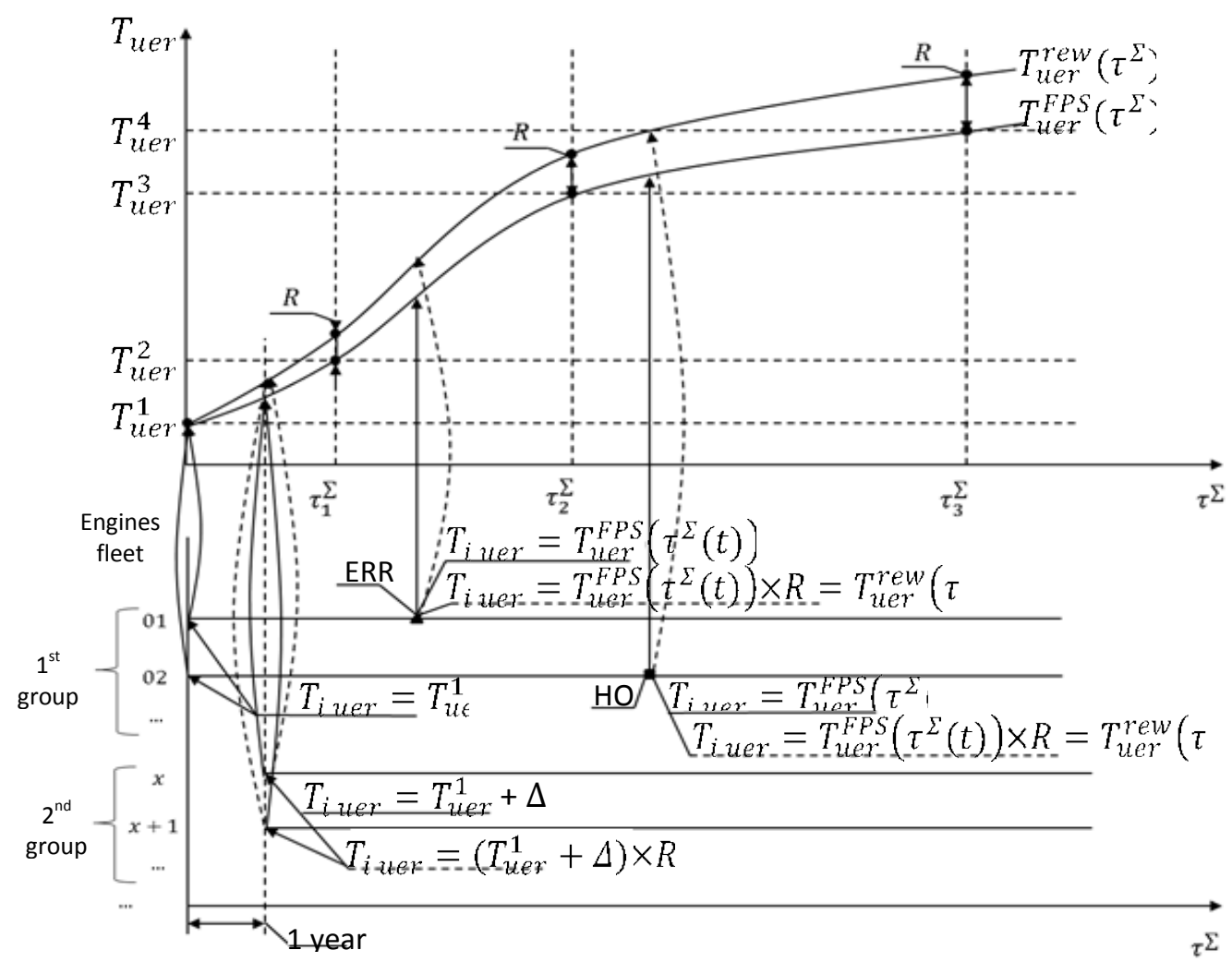

Fig. 2. A principle for modelling of improvement of operating time between unscheduled removals during operation

The third task, i.e. evaluation of the industry expenses aiming for reliability improvement above the requirements specified in the $\mathrm{RD}$, is quite a complex one. In spite of the enterprises keeping records of the expenses for engines reworks, the effect of their implementation, stated in reliability improvement, is problematic to evaluate due to a variety and interdependence of the factors affecting engines failures. Thus, engine failures may occur owing to engine structural imperfection (including both parameters chosen when designing which characterize operating process of an engine, and its elements performance), technology failure and manufacturing irregularity, low quality and insufficient material properties stability of the materials used in an engine, purchased parts defects as well as engines misuse and improper maintenance [1]. As a result, generation of unique dependence between expenses on engines reliability improvements and its planned values, which can be achieved while operating, is quite relative.

Nevertheless, a supposal may be introduced that the expenses for a certain engine rework in order to improve its reliability to $T_{i \text { uer }}^{r e w}$ level make a certain rate of a new engine prime cost (Formula 13):

$$
c(R)=k(R) *\left(1-M_{p r}\right) c_{n . e n},
$$

where $k(R)$ is a cost coefficient for the engine reliability improvement;

$R$ is a rate of increase of operating time between unscheduled removals above requirements specified in the RD;

$C_{n . e n}$ is a price of a new engine;

$M_{p r}$ is the prime contractor's profit margins.

$c(R)$ value is included into the prime contractor's expenses for heavy overhauls and emergency and recovery repairs of engines.

For the foregoing reasons, expert forecasting methods, for example Delphi method [6], can be used to build up dependence $k(R)$. The results objectivity can be increased if the experts are given operating data of the previous generations of the similar machinery; herewith it should be considered that dependence $k(R)$ should feature a downward-convex function for the further engines reliability improvement requires increasing efforts and industry expenses while they are perfected.

The results of the expert evaluation of $k(R)$ function can be tabulated (Table 1). 
Cost coefficients for engine reliability improvement

\begin{tabular}{|l|l|l|l|l|l|}
\hline$R$ & $R_{1}$ & $R_{2}$ & $R_{3}$ & $\cdots$ & $R_{\max }$ \\
\hline$k(R)$ & $k\left(R_{1}\right)$ & $k\left(R_{2}\right)$ & $k\left(R_{3}\right)$ & $\cdots$ & $k\left(R_{\max }\right.$, \\
\hline
\end{tabular}

In the present case, experts evaluate the maximum rate of reliability improvement $R_{\max }$ of a certain engine type taking into account existing and advanced technologies in aircraft engine making.

Definitely, the presented approach to evaluation of industry expenses for aircraft gasturbine engines reliability improvement is a simplified one. More perfected methods are quite completely investigated in other works $[3 ; 5 ; 7]$, though their application in the developed method will cause its over-complication and make it harder to widely implement the method into management practice.

\section{Analysis of results of technical and economic evaluation}

The proposed method is brought up to software implementation in $\mathrm{C}++$ programming language using graphics library Qt within Microsoft Visual Studio 2015 framework. The results of technical and economic evaluation for reliability improvement efficiency of the engines fleet operated within four-engine military transport aircrafts above the requirements specified in the $\mathrm{RD}$ are demonstrated in this section.

The input data assigned for modelling are presented in Table 2:

Major input data assigned for modelling

\begin{tabular}{|c|c|}
\hline Variable Name & Value \\
\hline \multicolumn{2}{|l|}{ MTA Group Properties } \\
\hline MTA group forming rate & 6 aircrafts/year \\
\hline MTA group forming period & 4 years \\
\hline Engines inventory & $3 \%$ of the total operating engines \\
\hline \multicolumn{2}{|l|}{ MTA Application Conditions in Peacetime } \\
\hline Planned flights table & $\begin{array}{l}\text { Distribution of typical flight } \\
\text { missions within a calendar year }\end{array}$ \\
\hline Average annual flight hours per 1 MTA & 500 hours \\
\hline \multicolumn{2}{|l|}{ Properties on Engines Reliability, Lifetime and Maintainability } \\
\hline $\begin{array}{l}\text { Dynamics of operating time between unscheduled engine removals off aircraft } \\
\text { according to the requirements specified in the RD }\end{array}$ & See Table 3 \\
\hline Time between engine overhauls & 4000 hours \\
\hline Assigned engine lifetime & 8000 hours \\
\hline Engine removal/mounting time & 24 hours \\
\hline \multicolumn{2}{|c|}{ The Properties of the Prime Contractor's Manufacturing Capacities and Repair Base } \\
\hline The prime contractor's base farness from the home base of the air regiment & $700 \mathrm{~km}$ \\
\hline Lead time for an emergency and recovery repair & 100 days \\
\hline Lead time for a heavy overhaul & 150 days \\
\hline \multicolumn{2}{|l|}{ Cost Parameters } \\
\hline A new engine price & $100 \mathrm{MU}$ \\
\hline Heavy overhaul price & $30 \mathrm{MU}$ \\
\hline Emergency and recovery repair price & $15 \mathrm{MU}$ \\
\hline $\begin{array}{l}\text { The prime contractor's cost behavior for increase of operating time between } \\
\text { unscheduled removals above the requirements specified in the RD }\end{array}$ & See Table 4 \\
\hline Transportation price for 1 engine per 1 kilometer & $5 \times 10^{-5} \mathrm{MU} / \mathrm{km}$ \\
\hline Price for keeping 1 engine in a warehouse for 1 hour & $10^{-5} \mathrm{MU} /$ hour \\
\hline The prime contractor's profit margins & $15 \%$ \\
\hline \multicolumn{2}{|l|}{ PBC Conditions } \\
\hline PBC validity period & 20 years \\
\hline Maximum amount of a performance payment & $125 \mathrm{MU}$ \\
\hline Performance payment function & See Table 5 \\
\hline Monitoring period for MTA group average availability & 6 months \\
\hline \multicolumn{2}{|l|}{ The Prime Contractor's Efforts to Improve Engines Reliability } \\
\hline Rate of improvement of engines reliability above the requirements specified in the RD & $0-50 \%$ \\
\hline
\end{tabular}


FPS for experimental development works to create an engine is a classified document, that's why traditional values of the operating time between unscheduled engine removals off aircrafts corresponding to the RD order of magnitude were used when modelling (Table 3).

Table 3

Dynamics of operating time between unscheduled engine removals off aircraft according to the requirements specified in the RD

\begin{tabular}{|c|c|c|c|c|}
\hline $\begin{array}{c}\text { The engines fleer total accumulated operating time, } \\
\text { hours }\end{array}$ & $\begin{array}{c}\text { At the state bench } \\
\text { testing stage }\end{array}$ & 30000 & 300000 & 800000 \\
\hline $\begin{array}{c}\text { Operating time between unscheduled engine removals } \\
\text { off aircrafts, h/uer }\end{array}$ & 5000 & 7000 & 9000 & 11000 \\
\hline
\end{tabular}

The prime contractor's cost behavior for increase of the operating time between unscheduled removals above the requirements specified in the
$\mathrm{RD}$ is presented at Table 4 . The prime contractor's cost coefficient increases linearly between the given intervals of reliability improvement rate.

Table 4

The prime contractor's cost behavior for increase of the operating time between unscheduled removals above the requirements specified in the $R D$

\begin{tabular}{|c|c|c|c|c|c|c|}
\hline $\begin{array}{c}\text { Rate of improvement of the engines reliability above the requirements specified } \\
\text { in the RD, \% }\end{array}$ & 0 & 10 & 20 & 30 & 40 & 50 \\
\hline The prime contractor's cost coefficient for engines reliability improvement, $\%$ & 0 & 0,001 & 0,005 & 0,02 & 0,05 & 0,2 \\
\hline
\end{tabular}

The performance payment function corresponds to examples provided in the foreign guidance documents on PBCs usage [20] and

involves conditions of cease-payment to the prime contractor, and granting of additional bonus payments (Table 5 ).

Table 5

The performance payments function

\begin{tabular}{|c|c|c|c|c|c|}
\hline The MTA group average availability for the monitoring period, $\%$ & $<80$ & 80 & 90 & 95 & $>98$ \\
\hline Rate from the maximum amount of performance payment, $\%$ & 0 & 50 & 80 & 100 & 110 \\
\hline
\end{tabular}

The described input data allow for modelling to be performed. Figures 3-5 show estimated change of technical and economic evaluation measures as a function of rate of increase of operating time between unscheduled removals above the requirements specified in the $\mathrm{RD}$. Every point on the curves corresponds to one modelling cycle.

Fig. 3 shows a direct dependence between the rate of increase of the operating time between unscheduled removals above the requirements specified in the RD and the MTA group availability level. Under the given engines properties and the MTA functioning conditions the rate of increase to $R=50 \%$ level corresponding to the final value of the operating time between unscheduled removals $T_{\text {uer }}^{\text {rew }}=16500$ h., allow for the MTA group availability to be increased by more than $3 \%$ due to reduction of unscheduled repairs number.

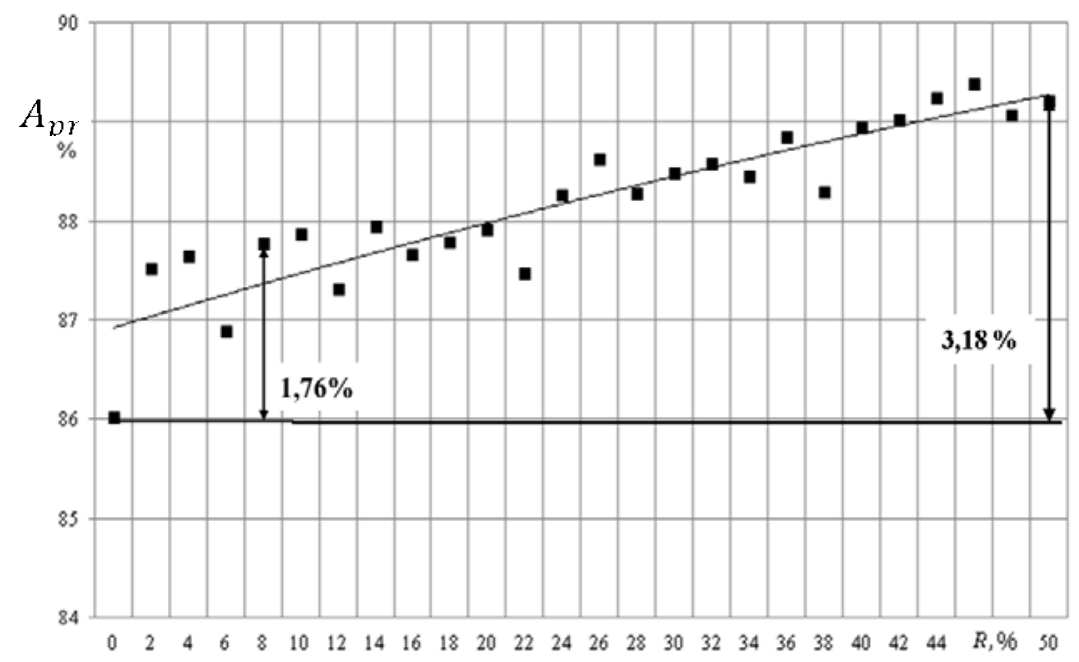

Fig. 3. The plot of the MTA group average availability during the PBC validity period as a function of the rate of increase of the operating time between unscheduled removals above the requirements specified in the RD 
Fig. 4 presents a function of the state customer's operating costs and the rate of increase of the operating time between unscheduled removals above the requirements specified in the RD. The positive dynamics of operating costs is accounted for by overgrowth of dynamics of the performance payments to the prime contractor over the dynamics of decrease of expenses for storage, transporting and new engines acquisition for the exchange of the decommissioned ones through a higher MTA group availability provided by the contractor. Considerable data scattering with respect to the trend line is due to the chosen PBC conditions: the performance payment function and the monitoring period of MTA group average availability. At large, growth of $R$ variable up to $50 \%$ will increase the state customer's operating costs by $12,4 \%$ under the specified input data.

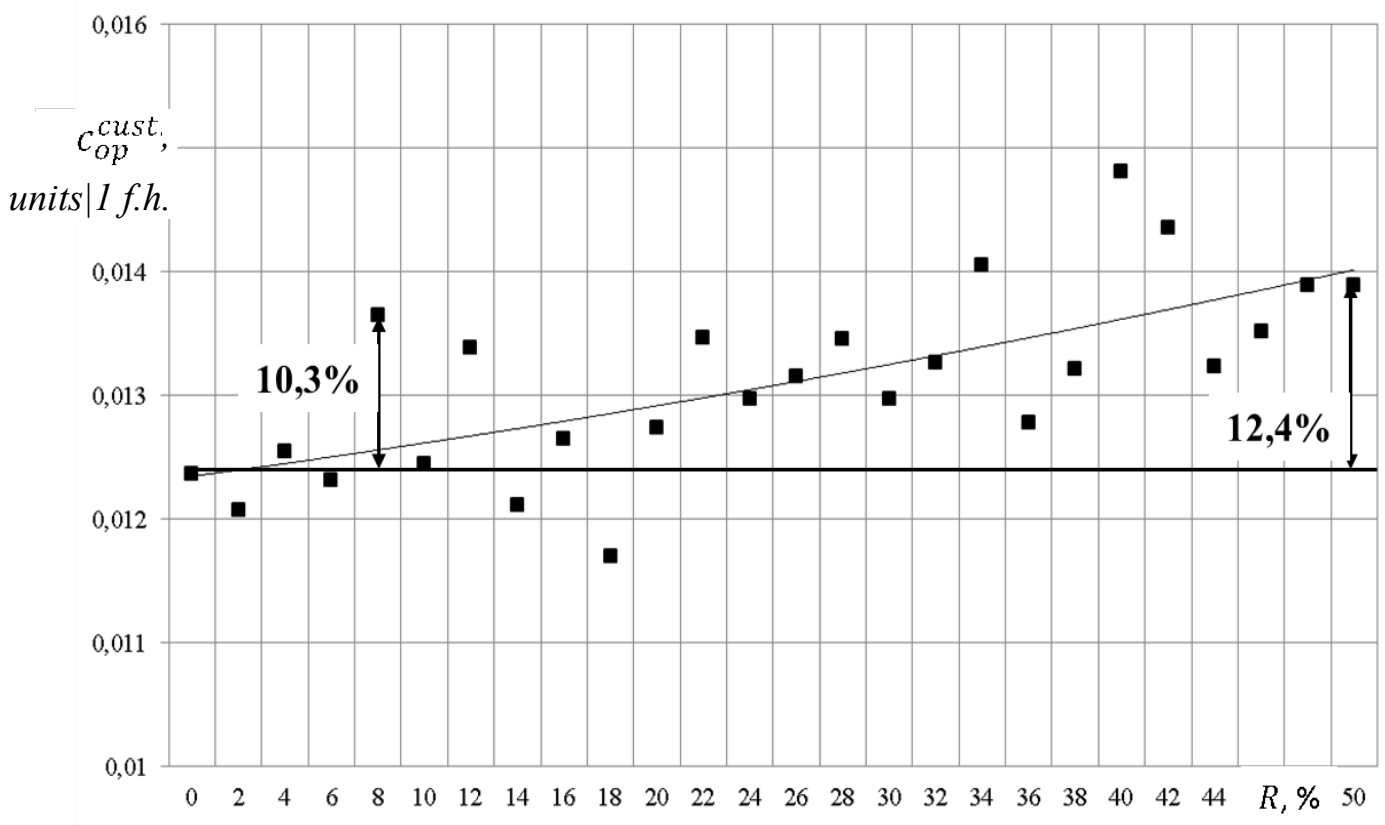

Fig. 4. The plot of the state customer's operating costs as a function of the rate of increase of operating time between unscheduled removals above the requirements specified in the RD

Fig. 5 demonstrates a function of the prime contractor's profit and the rate of increase of the operating time between unscheduled removals above the requirements specified in the $\mathrm{RD}$. This dependency is shaped as an upwardconvex function, provided by the following. Up to a point, the prime contractor's expenses for engine reworks do not exceed his additional income from providing higher MTA group availability. However the further engines reliability improvement requires increasing expenses from the manufacturer, eventually leading his profit to decrease.
Thus, taking into account the prime contractor's longing, as an in-market counterpart, to maximize his profit, the rate of increase of the operating time between unscheduled removals, exceeding the requirements specified in the RD by $8 \%$, is economically rational for him under the offered PBC conditions. The above value allows $26,5 \%$ increase of the prime contractor's profit, with its inevitable decrease under the conditions of traditional contrasts of "costs + " type. 


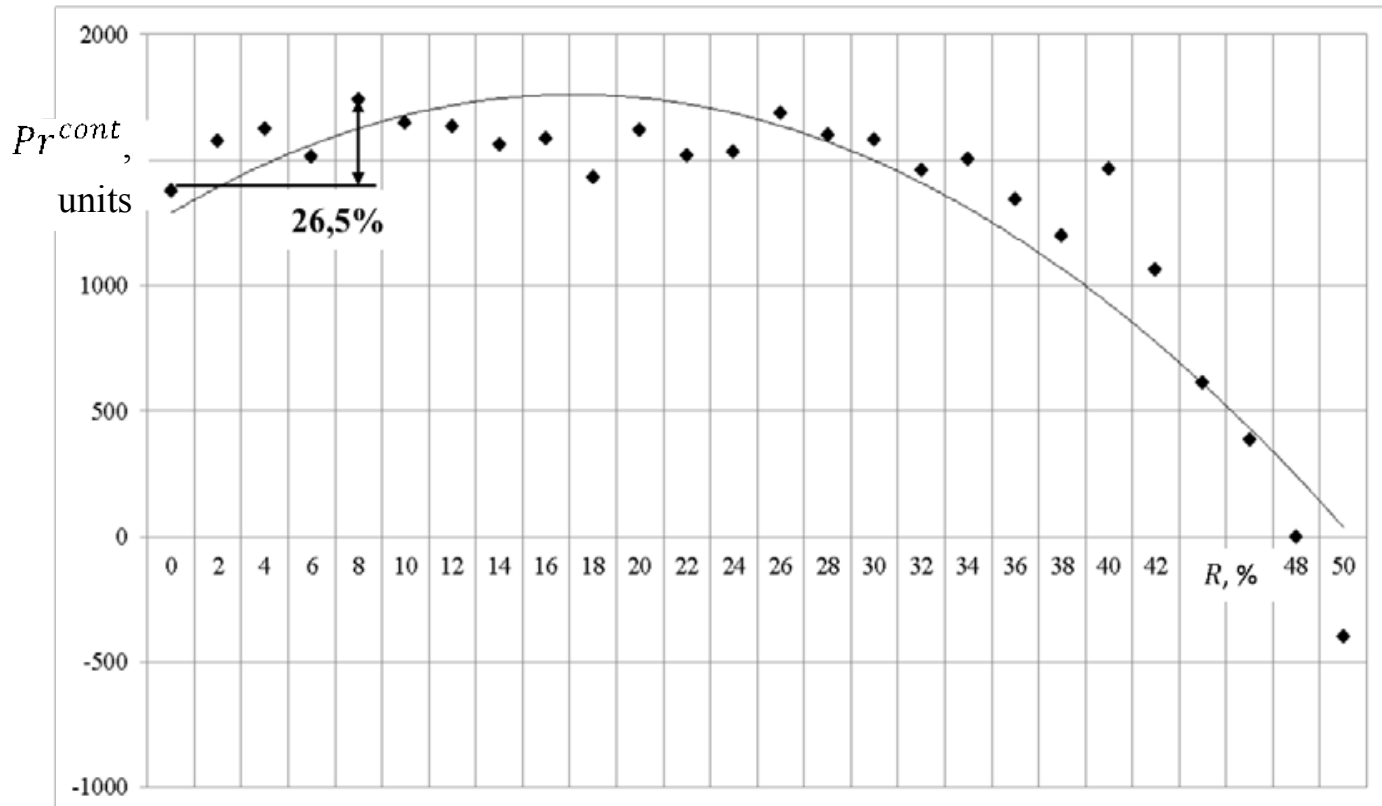

Fig. 5. The plot of the prime contractor's profit as a function of the rate of increase of the operating time between unscheduled removals above the requirements specified in the RD

Under the present value of $R$ variable, MAT group average availability is increased by $1,76 \%$, and the state customer's operating costs increase by $10,3 \%$.

It is worth noting that the offered method makes possible not only technical and economic reasoning of effectiveness of engines reliability improvement, but also can be used to determine optimal PBC conditions which provide the prime contractor's interest in engine reliability improvement up to the level which would allow for the state customer to operate the MTA group with maximum economic efficiency. The author will give exclusive attention to this issue in his future works.

It is worth noting that the offered method has broad modification capabilities to solve various problems faced by developers of PBC. So, in case of including to the methodology the block of optimization it is possible to solve the problem of finding the optimal PBC contract terms, using criteria of minimization the state customer's operating costs and maximization the prime contractor's profit. The solution of this problem is considered in another work [4].

\section{Conclusion}

The article provides a method for technical and economic evaluation of the effectiveness of reliability improvement of the engines operated within the military transport aircrafts group during their after-sales support under a performance-based contract (PBC). It is experimentally shown on this method basis that motivating mechanisms involved into PBC-contact allow making the prime contractor interested to improve engines reliability above the requirements specified in the regulatory documentation, which is not possible under the conditions of traditional "costs+" type contracts.

For the assigned input data, the rate of increase of operating time between unscheduled removals, exceeding the requirements specified in the regulatory documentation by $8 \%$, is economically rational for the prime contractor. It allows $26,5 \%$ increase of the prime contractor's profit, with average availability of the military transport aircrafts group during the $\mathrm{PBC}$ validity period being simultaneously increased by $1,76 \%$, and the state customer's operating costs being increased by $10,3 \%$.

\section{References}

1. Akims V.M. Bases of reliability of gas-turbine engines: the textbook for students of machine-building specialties of higher education institutions. Moscow, Mechanical engineering Publ., 1981. 207 p.

2. Akims V.M, Starik D.E., Morozov A.A. Economic efficiency of increase in a resource and reliability of gas-turbine engines. Moscow, Mechanical engineering Publ., 1972. 172 p. (in Russian).

3. Aleksandrovskaya L.N., Afanasyev A.P., Lisov A.A. Modern methods of ensuring non-failure operation of difficult systems. Moscow, Logos Publ., 2001. 208 p. (in Russian).

4. Asadullin M.R. The technique of definition of optimum terms of the contract of life cycle (on the example of aviation engine- 
building). What economic model is necessary to Russia? Materials II of the Perm congress of scientists-economists, 11 February, 2016. Perm, PSU Publ., 2016, pp.126-132. (in Russian).

5. Barzilovich Yu.E., Mezentsev V.G., Savenkov M.V. Reliability of aviation systems. Moscow, Transport Publ., 1982. 182 p. (in Russian).

6. Beshelev S.D., Gurvich F.G. Mathematico-statistical methods of expert estimates. Moscow, Statistics Publ., 1980. 264 p. (in Russian).

7. Questions of the mathematical theory of reliability under the editorship of B.V. Gnedenko. Moscow, Radio and communication Publ., 1983. 376 p. (in Russian).

8. Scraps V.V. Organizational and economic bases of ensuring competitiveness of hitech productions (on the example of aviation engine-building): thesis of the Doctor of Economics: 05.02.22. Moscow, 2007. 319 p. (in Russian).

9. Mikhaylov A.A. Model of operation of the park of engines taking into account use of strategy of resource management. The All-Russian scientific and technical conference "The scientific readings on aircraft devoted to $N$. E. memory of Zhukovsky". The collection of theses. Moscow, VVIA of the prof. N. E. of Zhukovsky Publ., 2004. (in Russian).

10. Lifelong contract. Bulletin of operational information "Moscow Auction", 2014, no.11. Available at: http://e-torgi.ru/index.php/st ati-2/7691-pozhiznennyj-kontrakt (accessed 03.03.2015). (in Russian).

11. Pisarev V.N. Application of the theory of mass service in problems of engineering and aviation providing. Moscow, VVIA of N.E. of Zhukovsky Publ., 1965. 44 p. (in Russian).

12. Rumyantsev E.A., Osovsky V.P., Protopopov V.A. Engineering and aviation ensuring fighting of parts of aircraft of armed forces and operation of the aviation equipment. Moscow, VVIA of N. E. of Zhukovsky Publ., 1989. 398 p. (in Russian).

13. Smirnov N.N. Scientific bases of creation of system of maintenance and repair of the GA planes. Moscow, MGTUGA Publ., 1994. 107 p. (in Russian).

14. Smirnov N.N., Itskovich A.A. Service and repair of the aircraft equipment on a state. 2nd edition added and processed. Moscow, Transport Publ., 1987. 272 p. (in Russian).

15. Chudayeva A.A. Reliability and service life of the equipment as economic category. Messenger of regional public institution, 2009, Issue 8 (102), pp. 150-155. (in Russian).

16. Aguilar M., Estrada G., Myers J. Decision-support quantitative models for valuing incentives in performance-based contracts. Monterey, CA, Naval Postgraduate School Publ., 2005. 112 p. (in Russian).

17. Deloitte Consulting LLP. Performance based logistics in aerospace \& defense. A rapidly growing market providing lower overall sustainment costs for military equipment and profitable growth opportunities for defense contractors. Available at: http://www.deloitte.com.br/publicacoes/2007/Perf ormance_Based_Logistics_in_A\&D.pdf (accessed 29.12.2014). (in Russian).

18. Guajardo J., Cohen A., Kim S., Netessine S. Impact of performance-based contracting on product reliability: an empirical analysis. Available at: http://faculty.som. yale.edu/sangkim/PBC-Reliability-Empirical.pdf (accessed 03.03.2015).

19. Kim S., Cohen M, Netessine S. Reliability or inventory? Analysis of product support contracts in the defense industry. Available at: http://sites.insead.edu/facultyres earch/research/doc.cfm?did=47947 (accessed 14.11.2015).

20. PBC Discussion Paper Vol 1.0. Next generation performance-based support contracts Achieving the Outcomes that Defence Requires. Available at: http://www.defence.gov.au/dmo/ Multimedia/Next_GPBSC-9-5978.pdf (accessed 15.03.2015).

21. Randall W., Nowicki D., Hawkins T. Explaining the effectiveness of performancebased logistics: a quantitative examination. The International Journal of Logistics Management, 2011, vol. 22, issue 3, pp. 324-348. doi: http://dx.doi.org/10.1108/09574091111181354.

22. Sopranos K. Performance-based logistics helps Boeing boost mission readiness. Available at: http://www.boeing.com/news/fr ontiers/archive/2007/august/i_ids01.pdf (accessed 30.03.2015).

The date of the manuscript receipt: 10.05.2016. 


\section{МЕТОДИКА ТЕХНИКО-ЭКОНОМИЧЕСКОЙ ОЦЕНКИ ЭФФЕКТИВНОСТИ ПОВЫШЕНИЯ НАДЕЖНОСТИ АВИАЦИОННЫХ ГАЗОТУРБИННЫХ ДВИГАТЕЛЕЙ ВОЕННОГО НАЗНАЧЕНИЯ ПРИ ИХ ПОСЛЕПРОДАЖНОМ ОБСЛУЖИВАНИИ ПО НОРМИРУЕМЫМ ПОКАЗАТЕЛЯМ КОНЕЧНОГО РЕЗУЛЬТАТА}

М.Р. Асадуллин, заместитель начальника отдела по работе с заказчиками АО «Авиадвигатель»

Электронный адрес: msmk_90@mail.ru

Акционерное общество «Авиадвигатель», 614990, Россия, г. Пермь, ГСП, Комсомольский пр-т, 93

Дается описание конфликта интересов государственного заказчика и головного исполнителя в вопросе повышения надежности авиационной техники в процессе еe послепродажного обслуживания. Показано, что конфликт интересов возникает при традиционном подходе к оплате услуг головного исполнителя по методу «издержки+». В качестве механизма разрешения конфликта интересов приводятся успешно применяемые за рубежом контрактные модели государственночастного партнерства со схемой оплаты услуг исполнителя по нормируемым показателям конечного результата послепродажного обслуживания авиационной техники. Длительный срок таких контрактов и независимость размера сервисных платежей от фактических затрат исполнителя стимулируют частного партнера к проведению мероприятий, направленных на повышение надежности техники. Показана актуальность проведения технико-экономической оценки эффективности таких мероприятий. Приводятся основные положения методики техникоэкономической оценки эффективности повышения надежности авиационной техники на примере парка двигателей, эксплуатируемых в составе расчетной группы военно-транспортных самолетов, при их послепродажном обслуживании по нормируемым показателям конечного результата. В основе методики лежит имитационная модель эксплуатации парка двигателей, позволяющая определять показатели технико-экономической оценки: средняя за период действия контракта исправность расчетной группы военно-транспортных самолетов, эксплуатационные затраты государственного заказчика и прибыль головного исполнителя. На основании разработанной методики экспериментально показано, что при послепродажном обслуживании парка двигателей по нормируемым показателям конечного результата у головного исполнителя существует экономическая заинтересованность в повышении надежности двигателей сверх заданных в нормативной документации требований.

Ключевые слова: технико-экономическая оценка, имитационное моделирование, исправность авиационной техники, конфликт интересов, послепродажное обслуживание, показатели конечного результата, авиационный газотурбинный двигатель, надежность авиационного двигателя, наработка на досрочный съем двигателя, военно-транспортный самолет.

Please cite this article in English as:

Asadullin M.R. Method for technical and economic evaluation of the effectiveness of reliability improvement of military aircraft gas-turbine engines in their aftersales support based on outcome performance measures // Vestnik Permskogo universiteta. Seria Ekonomika = Perm University Herald. Economy. 2016. № 3(30). P. 92-104. doi: 10.17072/1994-9960-2016-3-92-104 